BISMA

(Bisnis dan Manajemen)

\title{
Perancangan dan Pengukuran Sistem Kinerja Lingkungan untuk Mendukung Proper pada Industri Gas
}

\author{
Anindita Etri Wulandari ${ }^{1}$, Iwan Vanany ${ }^{2}$ \\ Institut Teknologi Sepuluh Nopember ${ }^{1,2}$ \\ Email korespondensi: anindita.etri@gmail.com
}

\begin{abstract}
Globalization effect and technology development which is accompanied by economic activity that involving the use of natural resources has created environmental issue in the oil and gas company. The issue of the environment is currently the main focus in improving concern for the environment and the improvement of the environmental performance of their company. PT X is a one of government company who has focus in midstream sector and downstream of gas industry in Indonesia has a role in gas trading, transportation, process and distribution. PT. X managing the gas transmission infrastructure in West and East Java, South and North Sumatra, Aceh and East Kalimantan. PT. X has mission to increase environmental performance through environmental friendly production process and reliable brand image. To accomplish their mission, these companies use ISO 14001: 2015 Environmental Management System and environmental company rating program (PROPER) as tools for environment performance evaluation but for measurement of the environmental performance, but PT X does not have the key of environment performance indicators (KEPI). Then, the result of KEPI identification used to design of the environmental performance system, which using methods for measurement such as Integrated Environment Performance Measurement System (IEPMS), Analytical Hierarchy Process (AHP), and Objective matrix (OMAX). Based on this research, there are 70 KEPI consisting of 51 KEPI quantitative and 19 KEPI qualitative. Total value of environment performance in PT. $X$ is 5.86, which is categorized into yellow color which means the company needs intensive controlling and evaluating to increase the company environment performance.
\end{abstract}

Keywords : Analytical Hierarchy Process (AHP); Environmental Performance System; Integrated Enviromental Performance Measurement System (IEPMS); KEPI; Objective Matrix (OMAX);PROPER

Received: 25 Juli 2017 Reviewed: 10 Oktober 2017 Accepted: 10 Oktober 2017 Published: 31 Oktober 2017

\section{PENDAHULUAN}

Saat ini pertumbuhan pesat industri dan pasar di Indonesia ditandai dengan adanya perubahan pola pikir konsumen dan dunia perindustrian. Pada sisi konsumen, selain masalah kualitas produk yang harus terjamin mutunya yang ditandai dengan sertifikat ISO, konsumen juga mulai menginginkan jaminan akan 
perlindungan dan kelestarian lingkungan dalam proses menghasilkan produk, hasil produk, sampai dengan sisa produk tersebut. Di dunia industri, terjadi perkembangan respon pemilik industri terhadap isu lingkungan yang berhubungan dengan kegiatan industrinya yaitu yang sebelumnya bersikap reaktif menjadi proaktif dan antisipatif. Hal ini dapat terlihat dari munculnya kesadaran masyarakat internasional akan berbagai fenomena global tentang lingkungan yang terjadi saat ini dan yang akan terjadi di masa datang.

Seiring dengan pertumbuhan perindustrian, penggunaan sumber daya alam dalam kegiatan produksi maupun pasca produksi menjadi salah satu faktor penyebab timbulnya pencemaran dan kerusakan lingkungan yaitu pencemaran air dan tanah, polusi udara, dan terganggunya habitat flora dan fauna. Di masa datang, sumber daya alam yang tersedia sebagai input kegiatan perindustrian akan semakin langka, peraturan perundangan mengenai perlindungan lingkungan dan keselamatan dan kesehatan kerja semakin ketat, perkembangan pasar semakin kompetitif untuk menghasilkan produk yang ramah lingkungan, dan munculnya konsumen yang mempunyai kesadaran akan kelestarian lingkungan. Selain itu, tuntutan dari stakeholders untuk bertanggung jawab dalam upaya perlindungan dan kelestarian lingkungan. Kondisi ini membawa industri berupaya untuk bersaing dan memenangkan persaingan industri dan mendapatkan dukungan penuh dari stakeholders dengan upaya menilai kinerja usahanya. Penilaian kinerja tidak terbatas hanya pada sektor finansial saja akan tetapi juga penilaian terhadap kinerja lingkungan perusahaan.

Berawal dari fenomena kepedulian stakeholders dan masyarakat akan lingkungan, PT X sebagai merupakan perusahaan pemerintah yang bergerak di sektor midstream dan downstream industri gas di Indonesia meliputi usaha niaga gas, transportasi gas, pemrosesan gas dan distribusi gas, serta bisnis lainnya yang terkait dengan gas alam dan produk turunannya perlu melakukan tinjauan terhadap aktivitas yang berhubungan dengan lingkungan. Peninjauan aktivitas yang memiliki dampak lingkungan memerlukan biaya yang cukup besar dan secara langsung akan mempengaruhi anggaran biaya operasional yang dikeluarkan perusahaan khususnya untuk rencana jangka pendek perusahaan. Sebaliknya, dalam jangka panjang akan berdampak positif terutama citra dan reputasi perusahaan dimata konsumen secara nasional dan internasional dan meningkatkan dukungan dari seluruh stakeholders.

PT. X, saat ini memiliki 6 (enam) area operasional yang tersebar di 3 (tiga) pulau besar di Indonesia yaitu Sumatera, Jawa, dan Kalimantan telah mengimplementasikan sistem ISO 14001: 2015 Sistem Manajemen Lingkungan yaitu sistem pengelolaan lingkungan yang telah diterapkan di perusahaan yang sesuai dengan standar internasional. Berdasarkan sistem manajemen lingkungan yang telah dibangun tersebut, perusahaan merumuskan kebijakan keberlanjutan yang didalamnya terdapat aspek lingkungan kemudian menentukan tujuan, sasaran, dan program manajemen lingkungan. Akan tetapi, sistem manajemen ISO 
14001 belum diimplementasikan maksimal oleh perusahaan dimana penerapan ISO 14001 tidak tersusun dalam suatu hirarki yang terstruktur untuk menggambarkan kinerja lingkungan perusahaan secara keseluruhan yang bertujuan mengetahui indikator-indikator kinerja lingkungan dari perusahaan tersebut.

Seiring dengan perkembangan industri migas serta tuntutan dari stakeholders, PT. X harus semakin professional dalam pengelolaan sistem manajemen lingkungannya dan mengembangkan sistem kinerja lingkungan sehingga dapat mengukur dan mengevaluasi efektifitas program terkait dengan manajemen lingkungan. Selain ISO 14001, sejak tahun 2012, PT. X telah menerapkan sistem pengukuran kinerja lingkungan dengan menggunakan pendekatan peraturan perundangan yang ditetapkan oleh Pemerintah yaitu Peraturan Menteri Lingkungan Hidup no 3 Tahun 2014 tentang Program Penilaian Peringkat Kinerja Perusahaan (PROPER). Akan tetapi, pendekatan PROPER dirasakan masih kurang detail untuk tiap bidang industri karena perspektif yang digunakan mengacu pada kepentingan pemerintah dan kurang mengakomodasi kepentingan stakeholders perusahaan. Selain itu, ukuran kinerja yang digunakan dalam PROPER belum disesuaikan dengan model sistem manajemen lingkungan dan tidak tersusun dalam suatu hirarki yang terstruktur untuk menggambarkan kinerja lingkungan perusahaan secara keseluruhan sehingga diperlukan pendekatan lain yang lebih komprehensif.

Penelitian ini untuk mengakomodasi beberapa kekurangan dalam sistem pengukuran kinerja perusahaan yang digunakan perusahaan saat ini sehingga perlu dilakukan perancangan dan pengukuran kinerja lingkungan. Dengan adanya penelitian ini, perusahaan dapat mengidentifikasi aspek lingkungan dan indikator kinerja lingkungan serta mengetahui nilai kinerja lingkungan dari sistem pengukuran kinerja lingkungan yang telah dirancang kemudian dapat dilakukan evaluasi untuk tindakan pencegahan, pengawasan, dan perbaikan indikator kinerja lingkungan.

\section{METODE PENELITIAN}

Perancangan dan pengukuran sistem kinerja lingkungan dapat dilakukan dengan melakukan identifikasi aspek-aspek, dampak, dan indikator kinerja lingkungan perusahaan yang sesuai dengan kegiatan operasional perusahaan. Dari hasil identifikasi kemudian menghasilkan Key to Enviromental Performance Indicator (KEPI), melakukan pembobotan KEPI dengan Analytical Hierarchy Process (AHP), pengukuran KEPI dengan Objective Matrix dan Traffic Light System, serta memberikan rekomendasi perbaikan kinerja lingkungannya dengan harapan perusahaan dapat melakukan perbaikan dan pengawasan kinerja lingkungan. 


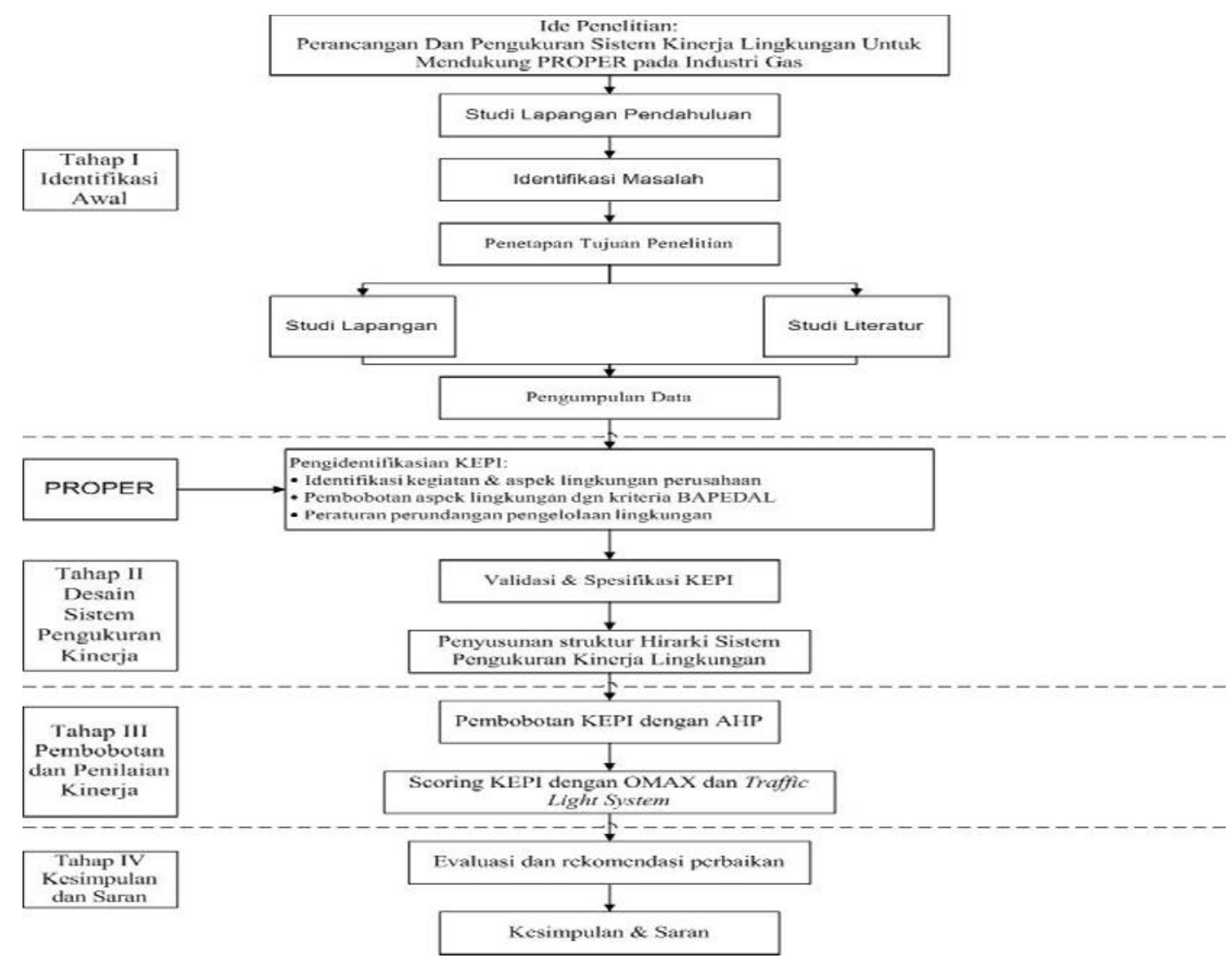

Gambar 1 Diagram Alir Penelitian

\section{Pengumpulan Data}

Tahap pengumpulan data dilakukan dengan cara pengamatan langsung di lapangan, wawancara dengan pihak-pihak yang berkepentingan (stakeholder), dan mencari sumber data organisasi untuk mengidentifikasikan aspek-aspek lingkungan yang akan menjadi Key to Environment Performance Indicator (KEPI), serta penyebaran kuisioner kepada orang-orang yang berkompeten terkait kegiatan operasional.

\section{Sistem Pengukuran Kinerja Lingkungan}

\section{Identifikasi Key to Environment Performance Indicator (KEPI)}

Tahap ini akan dirancang suatu indikator-indikator yang merupakan indikator kunci dari sistem pengukuran lingkungan. Indikator tersebut didapatkan dari identifikasi aspek-aspek lingkungan dari seluruh kegiatan operasional perusahaan. Selanjutnya, aspek-aspek lingkungan dari seluruh kegiatan perusahaan diidentifikasi untuk diberi pembobotan berdasarkan kriteria BAPEDAL. Evaluasi berdasarkan kriteria BAPEDAL ini bertujuan untuk mengetahui aspek lingkungan dari kegiatan proses produksi yang akan menimbulkan dampak cukup besar sehingga perlu diperhatikan sebagai indikator kinerja lingkungan. Aspek lingkungan yang dianggap signifikan sebagai dampak 
penting terhadap lingkungan apabila perkalian hasil pembobotan dari setiap subkriteria menghasilkan nilai lebih dari 6.750 (enam ribu tujuh ratus lima puluh).

\section{Validasi KEPI}

Setelah dilakukan penentuan KEPI pada tahap sebelumnya, hasil penentuan KEPI tersebut kemudan divalidasi agar memperoleh KEPI yang valid. Validasi tersebut dilakukan lewat interview dan pengisian kuisioner kepada pihak manajemen perusahaan yang mempunyai pengalaman dalam bidang lingkungan. Validasi KEPI tersebut didasarkan atas tingkat kepentingan dan tingkat kebutuhan KEPI.

\section{Penyusunan Struktur Hirarki Sistem Pengukuran Kinerja Lingkungan}

Setelah didapatkan hasil rancangan KEPI melalui interview kepada pihak manajemen perusahaan, maka disusun Struktur Hirarki Sistem Manajemen Lingkungan mulai dari KEPI Kuantitatif sampai dengan KEPI Kualitatif.

\section{Pembobotan KEPI}

Setelah KEPI diperoleh, maka dilakukan pembobotan dari KEPI tersebut. Proses pembobotan dilakukan dengan menggunakan metode Analitycal Hierarchy Process (AHP) melalui penyebaran kuesioner kepada pihak manajemen dan stakeholders perusahaan sehingga didapatkan bobot setiap ukuran performansi. Selanjutnya rancangan sistem pengukuran yang didapatkan siap diimplementasikan pada sistem perusahaan.

\section{Scoring System}

Scoring system digunakan untuk penilaian masing-masing KEPI sehingga dapat diketahui KEPI tersebut dalam posisi aman atau tidak dilakukan dengan memberikan score tiap-tiap KEPI. Hal ini juga dilakukan untuk mengetahui nilai pencapaian terhadap target masing-masing KEPI. Metode scoring system yang digunakan yaitu Objective Matrix (OMAX) dan pengklasifikasiannya menggunakan metode Traffic Light System untuk mengetahui apakah score pada KEPI yang bersangkutan mengindikasikan suatu perbaikan. Ketentuan nilai-nilai dalam Traffic Light System yang digunakan adalah sebagai berikut. $3 \geq$ nilai skor $\geq 0$ : KEPI masuk dalam kategori warna merah sehingga memerlukan tindakan perbaikan secepatnya. $8 \geq$ nilai skor $\geq 3$ : KEPI masuk dalam kategori warna kuning sehingga memerlukan pengawasan yang lebih intensif. $10 \geq$ nilai skor $\geq 8$ : KEPI masuk dalam kategori warna hijau sehingga tidak memerlukan tindakan perbaikan namun tindakan pengawasan tetap perlu dilakukan. 


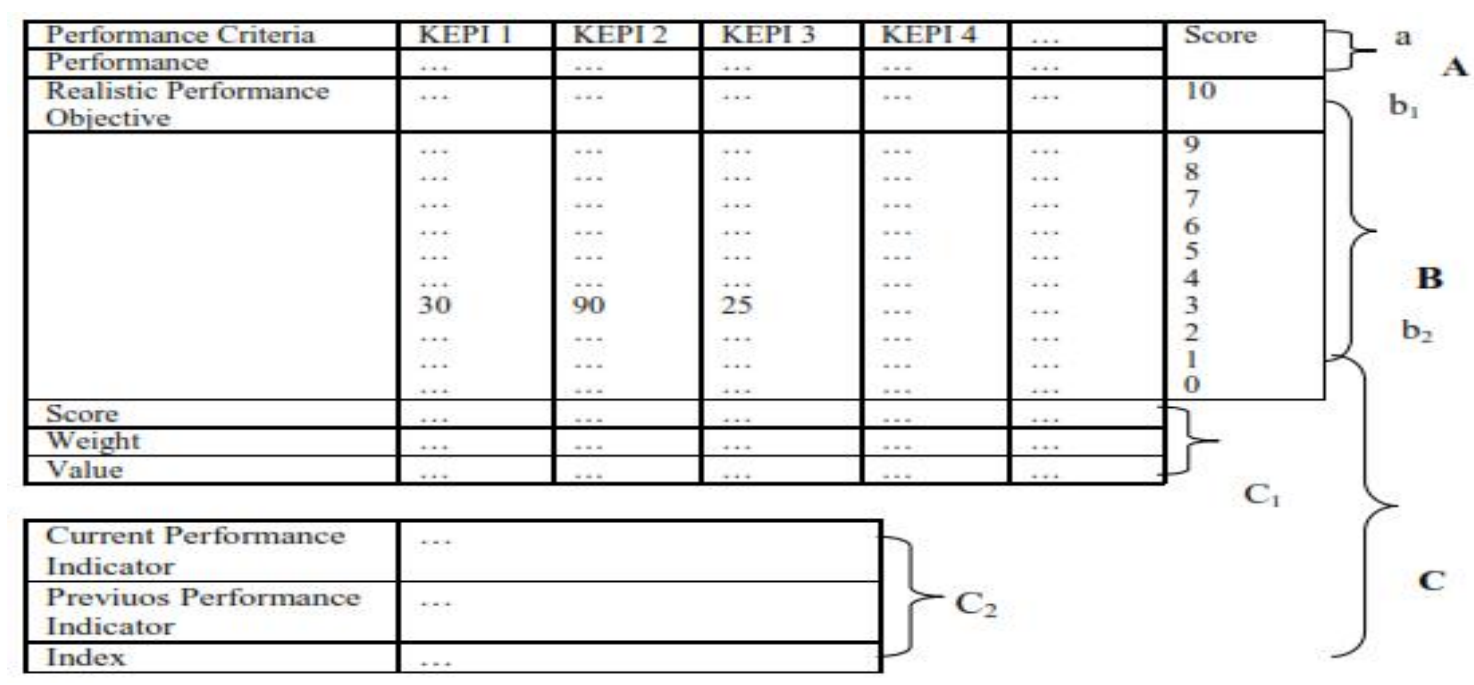

Gambar 2 Contoh Tampilan Tabel Objective Matrix

\section{Evaluasi dan Rekomendasi Perbaikan}

Selanjutnya dilakukan evaluasi terhadap hasil pengukuran kinerja lingkungan, agar dapat memberikan rekomendasi perbaikan terhadap indikatorindikator kinerja lingkungan yang tidak sesuai dengan target atau sasaran lingkungan yang telah ditetapkan.

\section{HASIL DAN PEMBAHASAN}

\section{Perancangan dan Pengukuran Kinerja Lingkungan}

Perancangan Sistem Pengukuran Kinerja Lingkungan menggunakan integrasi dari model sistem manajemen lingkungan yang menganut prinsip PlanDo-Check-Act (PDCA) dengan konsep IEPMS (Integrated Environment Performance Measurement System). Tujuan digunakannya model IEPMS adalah untuk mendapatkan suatu proses yang terstruktur untuk mencapai peningkatan secara berkelanjutan dalam pengelolaan lingkungan. Penilaian kinerja lingkungan dengan menggunakan metode IEPMS, akan mempertimbangkan dua ukuran yaitu kuantitatif dan kualitatif, sehingga hasil yang didapatkan akan lebih terintegrasi. Untuk melakukan perancangan KEPI, maka dilakukan studi secara menyeluruh mengenai identifikasi kegiatan produksi.

Pengukuran kinerja lingkungan dilakukan pada PT. X berdasarkan kinerja perusahaan pada periode I tahun 2015 dan periode II tahun. Pengukuran kinerja lingkungan dilakukan dengan metode Objective matrix (OMAX) dengan menggunakan pembobotan hasil dari Analytical Hierarchy Process (AHP).

Berdasarkan hasil penilaian kinerja lingkungan perusahaan secara keseluruhan pada PT. X menggunakan IEPMS (Integrated Environment Performance Measurement System), didapatkan 21 KEPI kategori warna merah, 14 KEPI kategori warna kuning, dan 35 KEPI kategori warna hijau. Nilai total yang didapatkan sebesar 5,86, di mana untuk nilai kuantitatif sebesar 2,262 dan 
nilai kualitatif sebesar 3,598. Nilai tersebut menunjukkan bahwa kinerja lingkungan perusahaan selama waktu pengamatan untuk penelitian ini berada pada kategori warna kuning. Dengan demikian, perlu adanya pengawasan yang lebih ketat dan intensif terhadap KEPI tersebut. Sedangkan untuk KEPI dalam kategori warna merah perlu segera dilakukan tindakan perbaikan (improvement). Beberapa KEPI dalam kategori merah ditunjukkan pada Tabel 1.

Tabel 1 KEPI Kategori Warna Merah

\begin{tabular}{lll}
\hline No KEPI & \multicolumn{1}{c}{ KEPI } & Value \\
\hline $\mathbf{7}$ & $\mathrm{pH}$ & 0.030 \\
\hline $\mathbf{8}$ & $\sum$ beban emisi GRK $\left(\mathrm{CH}_{4}\right)$ & 0.162 \\
\hline $\mathbf{9}$ & $\sum$ beban emisi GRK $\left(\mathrm{CO}_{2}\right)$ & 0.000 \\
\hline $\mathbf{1 0}$ & $\sum$ beban emisi GRK $\left(\mathrm{CH}_{4}\right)$ & 0.000 \\
\hline $\mathbf{1 1}$ & $\sum$ beban emisi GRK $\left(\mathrm{N}_{2} \mathrm{O}\right)$ & 0.000 \\
\hline $\mathbf{1 2}$ & $\sum$ beban emisi konvensional $(\mathrm{NOx})$ & 0.000 \\
\hline $\mathbf{1 3}$ & $\sum$ beban emisi konvensional $(\mathrm{PM})$ & 0.000 \\
\hline $\mathbf{1 4}$ & $\sum$ beban emisi konvensional $(\mathrm{SOx})$ & 0.000 \\
\hline $\mathbf{2 6}$ & Kebisingan $(\mathrm{dBa})$ & 0.0618 \\
\hline $\mathbf{2 7}$ & Kebisingan 24 jam $(\mathrm{dBa})$ & 0.0146 \\
\hline $\mathbf{2 8}$ & $\sum$ beban emisi GRK $\left(\mathrm{CO}_{2}\right)$ & 0.0766 \\
\hline $\mathbf{2 9}$ & $\sum$ beban emisi GRK $\left(\mathrm{CH}_{4}\right)$ & 0.000 \\
\hline $\mathbf{3 0}$ & $\sum$ beban emisi GRK $\left(\mathrm{N}_{2} \mathrm{O}\right)$ & 0.000 \\
\hline $\mathbf{3 6}$ & $\sum$ beban emisi Konvensional $(\mathrm{NOx})$ & 0.0123 \\
\hline $\mathbf{3 8}$ & Kadar pH & 0.0027 \\
\hline $\mathbf{3 9}$ & Kadar BOD & 0.000 \\
\hline $\mathbf{4 2}$ & Kadar Minyak dan Lemak & 0.000 \\
\hline $\mathbf{5 0}$ & $\sum$ HSE Meeting per bulan & 0.000 \\
\hline $\mathbf{5 1}$ & $\sum$ kejadian kebocoran gas & 0.01136 \\
\hline $\mathbf{5 8}$ & Jumlah program pelatihan lingkungan di & 0.000 \\
\hline $\mathbf{6 4}$ & dalam dan di luar perusahaan/tahun & \\
\hline & Jumlah program pelatihan K3 di dalam & 0.000 \\
\hline & dan di luar perusahaan/tahun & \\
\hline
\end{tabular}

Susunan hirarki sistem pengukuran kinerja lingkungan berdasarkan hasil validasi aspek lingkungan (Key Environment Performance Indicator), disertai dengan pengklasifikasian berdasarkan Traffic Light System ditunjukkan pada Gambar 3.

\section{Perumusan Upaya Peningkatan Kinerja Lingkungan}

Perumusan perbaikan kinerja lingkungan berdasarkan hasil Scoring System dengan metode OMAX dan traffic light system dimana didapatkan 21 KEPI kategori merah sehingga diperlukan suatu upaya perbaikan dan peningkatan kinerja dalam upaya pencapaian PROPER PT. X. Perumusan upaya perbaikan kinerja lingkungan didapatkan dari expert consultant PT. X yang telah melakukan pemetaan kondisi operasional dan aspek lingkungan untuk seluruh wilayah operasi dan inovasi dari tim Manajemen Lingkungan di seluruh area operasional. 
Beberapa rekomendasi usulan perbaikan untuk KEPI Merah ditunjukkan dalam lampiran 1.

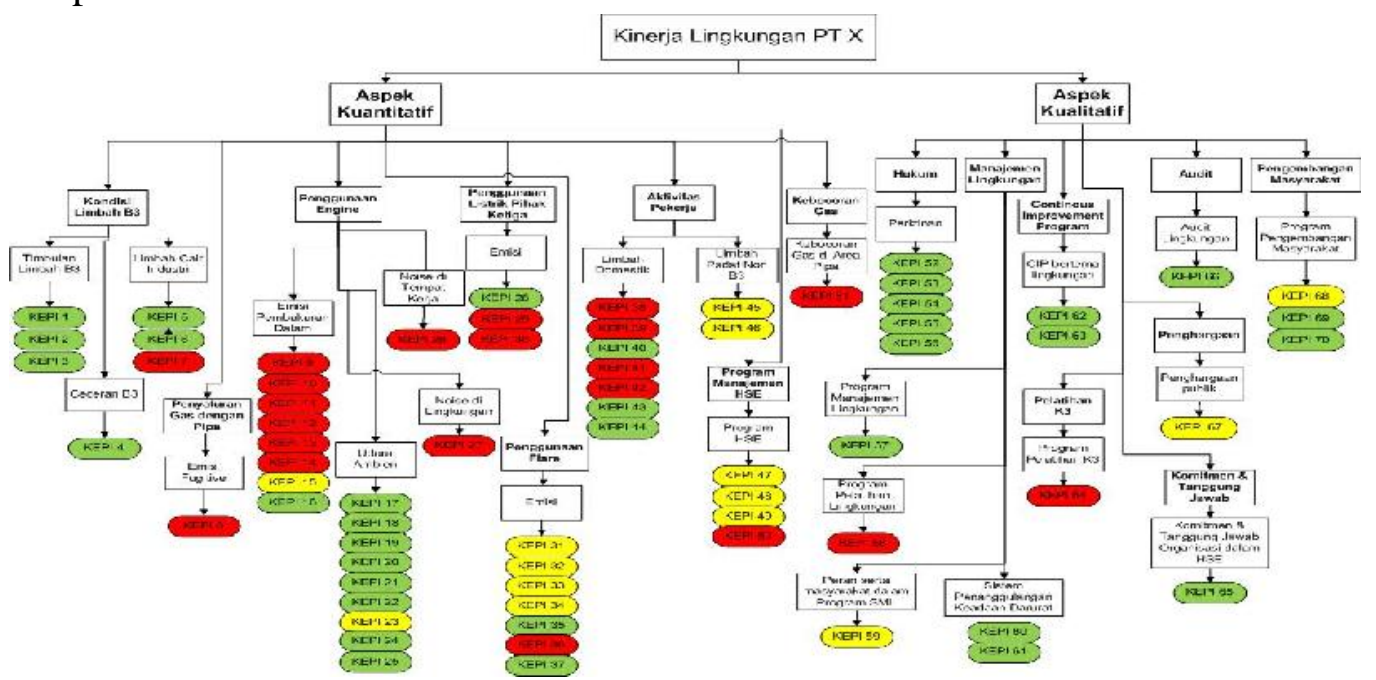

Gambar 3 Hirarki Sistem Pengukuran Kinerja Lingkungan dengan

Pengklasifikasian Traffic Light System

\section{KESIMPULAN}

Berdasarkan analisis dan pembahasan penilaian kinerja lingkungan untuk mendukung PROPER pada industri gas, didapatkan kesimpulan bahwa hasil identifikasi kegiatan operasional dan aspek lingkungan menghasilkan 8 aspek lingkungan yang paling berpengaruh secara siginifikan dalam kegiatan operasional PT X dan 70 KEPI yang terdiri dari 51 KEPI kuantitatif dan 19 KEPI kualitatif. Hasil pengukuran kinerja lingkungan PT X yang diperoleh dari hasil pembobotan dengan metode AHP dan Scoring System yaitu terdapat 21 KEPI kategori warna merah, 14 KEPI kategori warna kuning, dan 35 KEPI kategori warna hijau dan score sebesar 5.86 dimana dalam pengklasifikasian dengan Traffic Light System masuk dalam kategori warna kuning yang berarti bahwa kinerja lingkungan PT X masih perlu dilakukan pengawasan dan perbaikan oleh pihak perusahaan.

Upaya perbaikan kinerja lingkungan dan upaya mendukung PROPER pada PT. X yang dapat dilakukan sebagai berikut yaitu memperbaiki sistem pengolahan air limbah industri (API Separator), melaksanakan inspeksi rutin sambunngan antar pipa dan intrumentasiuntuk meminimalisir adanya kebocoran gas, melaksanakan PM (Preventive Maintenance) Genset dan Kompressor, membuat enclosure untuk mengurangi paparan kebisingan yang dihasilkan oleh engine, penggantian \& Modifikasi Lampu Ruang Kerja/Indoor dan Outdoor (TL atau Mercury ke LED),mengurangi jumlah shutdown stasiun dengan membuat aplikasi Generator Management System (GMS), membuat sistem pengolahan air limbah domestik yang sederhana untuk seluruh wilayah kerja PT X, membuat jadwal program HSE Meeting untuk seluruh fungsi dalam area kerja operasional PT X, membuat sistem monitoring kebocoran gas untuk peralatan instrumentasi dan 
sambungan antar pipa, membuat Training Need Analysis untuk seluruh jabatan yang berada di wilayah operasional PT $\mathrm{X}$ dan yang terlibat dalam Sistem Manajemen Lingkungan.

Saran yang dapat diberikan oleh penulis untuk penelitian selanjutnya yaitu perlu adanya penelitian lebih lengkap dan berjangka panjang untuk mendapatkan indikator kinerja lingkungan atau KEPI yang lebih lengkap dan akurat dan pengkajian lebih lanjut dalam upaya peningkatan kinerja lingkungan untuk mendukung PROPER dengan memperhatikan faktor biaya.

\section{REFERENSI}

Anggraeni, Kirana, et al. 2013. Perancangan Sistem Pengukuran Kinerja Lingkungan Dengan Pendekatan Integrated Enviromental Performance Measurement System - AHP. Tugas Akhir Jurusan Teknik Industri Universitas Sultan Ageng Tirtayasa. Serang.

Bapedalda Jawa Timur. 2016. Himpunan Peraturan Perundangan Lingkungan Hidup. Bapedal Jatim. Surabaya.

Darsono, Valentinus. 1995. Pengantar Ilmu Lingkungan. Universitas Atma Jaya. Yogyakarta.

Dongdaijae, A. 2000. Development Of Environmental Performance Indicators For Textile Process And Product. Journal of Cleaner Production, 8 : 473481.

Gemi. 2001. Environment Value to The Top Line. Global Environmental Management Initiatives. Washington DC.

Jones, L.G. 2006. Environmental Key Performance Indicator, Reporting Guidelines for UK Business. Queen's Printer and Controller. London.

Kusumawardani, I.W. 2008. Pengukuran Kinerja Lingkungan dengan Metode MCDM-AHP dan Integrated Environment Performance Measurement System (IEPMS) (Studi Kasus : Pabrik Gula Jombang Baru, Jombang). Tugas Akhir Jurusan Teknik Industri ITS. Surabaya.

Prianto, T.S. 2003. Pengukuran Kinerja Lingkungan Dengan Menggunakan Metode Integrated Performance Measurement System dan PROPER (Studi Kasus Di PT. Petrokimia Gresik). Tugas Akhir Teknik Industri ITS, Institut Teknologi Sepuluh Nopember. Surabaya.

Purwanto, A.T. 2000. Pengukuran Kinerja Lingkungan. http://andietri.tripod.com/index.htm. Diakses tanggal 10 November 2016.

Rachmawati, Silvia. 2010. Pengukuran Kinerja Lingkungan Dengan Metode Analytical Hierarchy Process (AHP) Dan Integrated Environment Performance Measurement System (IEPMS) pada PT. Campina Ice Cream Industry. Tugas Akhir Manajemen Industri ITS Institut Teknologi Sepuluh Nopember. Surabaya. 
Riggs, J.L. 1987. Productivity Measurement by Objectives. In National Productivity Review. Autumn.

RKZ. 2015. Laporan Sosial Mapping Desa Penatarsewu Kecamatan Tanggulangin Kabupaten Sidoarjo Provinsi Jawa Timur. Laporan Sosial Mapping Pertamina Gas Eastern Java Area. Surabaya.

Saaty, T.L. 1996. Decision Making with Dependence And Feedback The Analytic Network Process. Pittsburgh : RWS Publications. USA.

Saaty, T.L. 1999. Fundamentals of the Analytic Process, www.isahp2003.net, ISAHP 1999; Kobe, Japan, August 12 -14.

Stutz, Markus, et.al. 2004. Key Environmental Performance Indicators (KEPIs): A New Approach to Environmental Assessment. http://www.lcainfo.ch/DF/DF27/Stutz2KEPIPaper2004.pdf . Diakses tanggal 1 November 2016.

Sunu, P. 2001. Melindungi Lingkungan Dengan Menerapkan ISO 14001. PT. Gramedia Widiasarana Indonesia. Jakarta.

Lampiran 1. Usulan Perbaikan KEPI Merah

\begin{tabular}{|c|c|c|c|}
\hline $\begin{array}{c}\text { No } \\
\text { KEPI } \\
\end{array}$ & $\begin{array}{c}\text { Aspek } \\
\text { Lingkungan } \\
\end{array}$ & KEPI & Usulan Perbaikan \\
\hline 7 & $\begin{array}{l}\text { Limbah Cair } \\
\text { Industri }\end{array}$ & $\mathrm{pH}$ & $\begin{array}{l}\text { a. Melakukan monitoring } \mathrm{pH} \text { rutin bulanan di } \\
\text { sumber limbah cair industri (API Separator) } \\
\text { b. Memperbaiki sistem pengolahan air limbah } \\
\text { industri (API Separator) }\end{array}$ \\
\hline 8 & Emisi Fugitive & $\begin{array}{l}\sum \text { beban emisi } \\
\text { GRK }\left(\mathrm{CH}_{4}\right)\end{array}$ & $\begin{array}{l}\text { a. Melakukan invetarisasi ulang sumber emisi } \\
\text { fugitive yang ada di seluruh wilayah } \\
\text { operasional PT X } \\
\text { b. Melaksanakan inspeksi rutin sambunngan } \\
\text { antar pipa dan intrumentasiuntuk } \\
\text { meminimalisir adanya kebocoran gas } \\
\text { c. Menggunakan metode perhitungan emisi } \\
\text { fugitive yang seragam untuk seluruh wilayah } \\
\text { operasional PT X } \\
\text { d. Membuat rencana strategis untuk mengurangi } \\
\text { beban emisi pencemaran } \mathrm{CH}_{4} \text { yaitu } \\
\text { melakukan review terhadap desain } \\
\text { pembangunan pipa baru dengan } \\
\text { meminimalisir adanya sambungan (flange) }\end{array}$ \\
\hline 9 & \multirow{6}{*}{$\begin{array}{l}\text { Emisi } \\
\text { Pembakaran } \\
\text { Dalam }\end{array}$} & $\begin{array}{l}\sum \text { beban emisi } \\
\text { GRK }\left(\mathrm{CO}_{2}\right)\end{array}$ & \multirow{6}{*}{$\begin{array}{l}\text { Membuat rencana strategis untuk mengurangi } \\
\text { beban emisi pembakaran dalam dari kegiatan } \\
\text { operasional engine yaitu: } \\
\text { a. Melaksanakan PM (Preventive Maintenance) } \\
\text { Genset dan Kompressor dilakukan dengan: } \\
\text { - } 3 \text { Bulan sekali dengan task list : visual } \\
\text { inspeksi, cek kebocoran dan greasing } \\
\text { program } \\
\text { - } 1 \text { Bulan sekali dengan task list analisa } \\
\text { vibrasi } \\
\text { - } 6 \text { Bulan sekali dengan task list : Infrared } \\
\text { Thermography } \\
\text { - } 3 \text { Bulan sekali dengan task list : Lubricant }\end{array}$} \\
\hline 10 & & $\begin{array}{l}\sum \text { beban emisi } \\
\text { GRK }\left(\mathrm{CH}_{4}\right)\end{array}$ & \\
\hline 11 & & $\begin{array}{l}\sum \text { beban emisi } \\
\text { GRK }\left(\mathrm{N}_{2} \mathrm{O}\right)\end{array}$ & \\
\hline 12 & & $\begin{array}{l}\sum \text { beban emisi } \\
\text { konvensional } \\
(\mathrm{NOx})\end{array}$ & \\
\hline 13 & & $\begin{array}{l}\sum \text { beban emisi } \\
\text { konvensional } \\
(\mathrm{PM})\end{array}$ & \\
\hline 14 & & $\sum$ beban emisi & \\
\hline
\end{tabular}




\begin{tabular}{|c|c|c|c|}
\hline $\begin{array}{c}\text { No } \\
\text { KEPI } \\
\end{array}$ & $\begin{array}{c}\text { Aspek } \\
\text { Lingkungan } \\
\end{array}$ & KEPI & Usulan Perbaikan \\
\hline & & $\begin{array}{l}\text { konvensional } \\
\text { (SOx) }\end{array}$ & $\begin{array}{l}\text { Analysis } \\
\text { b. Melaksanakan Pembuatan kontrak overhaul } \\
\text { engine } \\
\text { c. Modifikasi Process Flow Diagram } \\
\text { penyaluran gas untuk menurunkan konsumsi } \\
\text { bahan bakar engine } \\
\text { d. Menggunakan metode perhitungan emisi } \\
\text { pembakaran dalam yang seragam untuk } \\
\text { seluruh wilayah operasional PT X } \\
\text { e. Penerapan manajemen transportasi kendaraan } \\
\text { operasional \& penggantian solar dengan } \\
\text { Biosolar dan premium dengan peratamax } \\
\text { untuk BBM kendaraan operasional }\end{array}$ \\
\hline 26 & $\begin{array}{l}\text { Noise di } \\
\text { Tempat Kerja }\end{array}$ & $\begin{array}{l}\text { Kebisingan } \\
(\mathrm{dBa})\end{array}$ & $\begin{array}{l}\text { a. Membuat enclosure untuk mengurangi } \\
\text { paparan kebisingan yang dihasilkan oleh }\end{array}$ \\
\hline 27 & $\begin{array}{l}\text { Noise di } \\
\text { Lingkungan }\end{array}$ & $\begin{array}{l}\text { Kebisingan } 24 \\
\text { jam }(\mathrm{dBa})\end{array}$ & $\begin{array}{l}\text { b. Menyediakan ear muff di area kerja yang } \\
\text { berhubungan dengan engine } \\
\text { c. Menyediakan rambu paparan kebisingan } \\
\text { untuk seluruh area kerja yang berhubungan } \\
\text { dengan engine } \\
\text { d. Pelaksanaan program penghijauan di seluruh } \\
\text { wilayah operasional }\end{array}$ \\
\hline 28 & \multirow{3}{*}{$\begin{array}{l}\text { Penggunaan } \\
\text { listrik dari } \\
\text { pihak ketiga }\end{array}$} & $\begin{array}{l}\sum \text { beban emisi } \\
\text { GRK }\left(\mathrm{CO}_{2}\right)\end{array}$ & \multirow{3}{*}{$\begin{array}{l}\text { Membuat rencana strategis untuk mengurangi } \\
\text { beban emisi penggunaan listrik dari pihak ketiga } \\
\text { yaitu: } \\
\text { a. Penggantian \& Modifikasi Lampu Ruang } \\
\text { Kerja/Indoor dan Outdoor (TL atau Mercury } \\
\text { ke LED) } \\
\text { b. Penggantian Monitor CRT ke LCD \& LED } \\
\text { c. Penggantian dan Pemasangan Lampu } \\
\text { Penerangan "Solar Cell" } \\
\text { d. Retrofit refrigerant AC dari Freon menjadi } \\
\text { e. Pusicool }\end{array}$} \\
\hline 29 & & $\begin{array}{l}\sum \text { beban emisi } \\
\text { GRK }\left(\mathrm{CH}_{4}\right)\end{array}$ & \\
\hline 30 & & $\begin{array}{l}\sum \text { beban emisi } \\
\text { GRK }\left(\mathrm{N}_{2} \mathrm{O}\right)\end{array}$ & \\
\hline 36 & $\begin{array}{l}\text { Penggunaan } \\
\text { Flare }\end{array}$ & $\begin{array}{l}\sum \text { beban emisi } \\
\text { Konvensional } \\
(\mathrm{NOx})\end{array}$ & $\begin{array}{l}\text { Membuat rencana strategis untuk mengurangi } \\
\text { beban emisi penggunaan flare yaitu: } \\
\text { a. Mengurangi jumlah shutdown stasiun dengan } \\
\text { membuat aplikasi Generator Management } \\
\text { System (GMS) } \\
\text { b. Mempercepat proses penerimaan cairan hasil } \\
\text { pigging pipa dengan mendesain sistem } \\
\text { penerimaan cairan hasil pigging dari satu } \\
\text { wilayah ke wilayah lain }\end{array}$ \\
\hline 38 & \multirow{2}{*}{$\begin{array}{l}\text { Limbah } \\
\text { domestik }\end{array}$} & Kadar pH & \multirow{2}{*}{$\begin{array}{l}\text { Membuat sistem pengolahan air limbah domestik } \\
\text { yang sederhana untuk seluruh wilayah kerja PT X }\end{array}$} \\
\hline$\frac{39}{42}$ & & $\begin{array}{l}\text { Kadar } \mathrm{BOD}_{5} \\
\text { Kadar Minyak } \\
\text { dan Lemak }\end{array}$ & \\
\hline 50 & Program HSE & $\begin{array}{l}\sum \text { HSE Meeting } \\
\text { per bulan }\end{array}$ & $\begin{array}{l}\text { a. Membuat jadwal program HSE Meeting } \\
\text { untuk seluruh fungsi dalam area kerja } \\
\text { operasional PT X } \\
\text { b. Memasukkan kegiatan HSE Meeting dalam } \\
\text { KPI per area kerja operasional }\end{array}$ \\
\hline 51 & $\begin{array}{l}\text { Kebocoran gas } \\
\text { di area pipa }\end{array}$ & $\begin{array}{l}\sum \quad \text { kejadian } \\
\text { kebocoran gas }\end{array}$ & $\begin{array}{l}\text { Membuat rencana kerja pemeriksaan bak } \\
\text { kontrol dan pemeriksaan jalur pipa }\end{array}$ \\
\hline
\end{tabular}


Anindita Etri Wulandari1, Iwan Vanany

Perancangan dan Pengukuran Sistem Kinerja Lingkungan untuk Mendukung Proper pada Industri Gas

\begin{tabular}{|c|c|c|c|}
\hline $\begin{array}{c}\text { No } \\
\text { KEPI } \\
\end{array}$ & $\begin{array}{c}\text { Aspek } \\
\text { Lingkungan } \\
\end{array}$ & KEPI & Usulan Perbaikan \\
\hline & & & $\begin{array}{ll}\text { b. } & \begin{array}{l}\text { Melaksanakan preventive } \\
\text { rutinseluruh instrumentasi } \\
\text { kegiatan penyaluran gas } \\
\text { pendukung }\end{array} \\
\text { c. } & \text { Membuat sistem monitoring kebocoran gas } \\
\text { untuk peralatan instrumentasi dan sambungan } \\
\text { antar pipa }\end{array}$ \\
\hline 58 & $\begin{array}{l}\text { Program } \\
\text { Manajemen } \\
\text { Lingkungan }\end{array}$ & $\begin{array}{l}\text { Jumlah program } \\
\text { pelatihan } \\
\text { lingkungan di } \\
\text { dalam dan di } \\
\text { luar } \\
\text { perusahaan/tahu } \\
\mathrm{n}\end{array}$ & $\begin{array}{l}\text { a. Membuat Training Need Analysis untuk } \\
\text { setiap pekerja yang terlibat dalam } \\
\text { Manajemen Lingkungan } \\
\text { b. Melakukan kerjasama dengan lembaga } \\
\text { pelatihan untuk melakukan pelatihan } \\
\text { lingkungan sesuai dengan ketentuan dalam } \\
\text { PROPER } \\
\text { c. Mengadakan in-house training dari hasil } \\
\text { pelatihan yang telah diikuti diluar }\end{array}$ \\
\hline 64 & $\begin{array}{l}\text { Program } \\
\text { Pelatihan K3 }\end{array}$ & $\begin{array}{l}\text { Jumlah program } \\
\text { pelatihan K3 di } \\
\text { dalam dan di } \\
\text { luar perusahaan } \\
\text { /tahun }\end{array}$ & $\begin{array}{l}\text { a. Membuat Training Need Analysis untuk } \\
\text { seluruh jabatan yang berada di wilayah } \\
\text { operasional PT X } \\
\text { b. Melakukan kerjasama dengan lembaga } \\
\text { pelatihan K3 } \\
\text { c. Mengadakan in-house training dari hasil } \\
\text { pelatihan yang telah diikuti diluar }\end{array}$ \\
\hline
\end{tabular}

